\title{
Chemical composition and fermentative characteristics of old man saltbush silage supplemented with energy concentrates
}

\section{Composição química e características fermentativas de silagem de erva sal aditivadas com concentrados energéticos}

\author{
Gherman Garcia Leal de Araújoㅜ; Genilson Amaral Santos²; Tadeu Vinhas \\ Voltolini $^{1}$; Salete Alves de Moraes ${ }^{1}$; Luiz Gustavo Ribeiro Pereira ${ }^{1}$; Glayciane \\ Costa Gois $^{3 *}$; Fleming Sena Campos ${ }^{4}$
}

\begin{abstract}
The objective of this study was to evaluate the fermentation profile and chemical composition of old man saltbush (Atriplex nummularia Lindl.) silage supplemented with cassava (Manihot esculenta Crantz) scraps or grain sorghum (Sorghum bicolor) in the proportion of $10 \%$ based on natural matter. The experimental design was completely randomized, in a $3 \times 7$ factorial arrangement $(3$ treatments and 7 opening days), with three replications. The treatments consisted of three silages: old man saltbush silage, old man saltbush silage + cassava scrap, and old man saltbush silage + grain sorghum. The experiment was conducted at the EMBRAPA Semiarid Animal Nutrition Laboratory, located in the city of Petrolina-PE. Twenty-one experimental silos were used for each treatment; these silos were opened after $1,3,5,7,14,28$, and 56 days in ensiling. The $\mathrm{pH}$, ammoniacal nitrogen and total nitrogen ratio, dry matter, crude protein, ether extract, mineral matter, organic matter, neutral detergent fiber, acid detergent fiber, total carbohydrates, non-fibrous carbohydrate, and dry matter in vitro digestibility. The additives

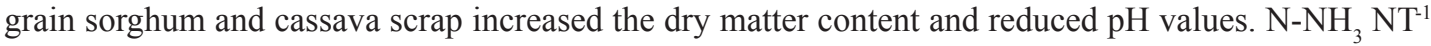
values increased as the fermentation processes progressed, and after 56 fermentation days were close to $11 \%$. Silages were classified as excellent in the fermentation process. The addition of cassava scrap and grain sorghum favors the ensiling process of the old man saltbush, providing improvements in the silage nutritive value. During the storage period, the use of these additives promoted a reduction of total losses, inhibition of alcoholic fermentation, and greater carbohydrates recovery, resulting in silage with a nutritive value similar to that of fresh forage, representing an alternative source of additives.
\end{abstract}

Key words: Foodstuffs. Forage conservation. Semi-arid. Supplementation.

\section{Resumo}

Objetivou-se com este trabalho avaliar o perfil fermentativo e a composição química da silagem de erva sal (Atriplex nummularia Lindl.) aditivada com raspa de mandioca (Manihot esculenta Crantz) ou sorgo grão (Sorghum bicolor) na proporção de $10 \%$ com base na matéria natural. O delineamento experimental

\footnotetext{
Pesquisadores, Empresa Brasileira de Pesquisa Agropecuária, EMBRAPA Semiárido, Bolsista PQ/CNPq, Petrolina, PE, Brasil. E-mail: gherman.araujo@embrapa.br; tadeu.voltolini@embrapa.br; salete.moraes@embrapa.br; luiz.gustavo@embrapa.br

2 M.e em Ciência Animal, Programa de Pós-Graduação em Ciência Animal, Universidade Federal do Vale do São Francisco, UNIVASF, Petrolina, PE, Brasil. E-mail: genamaral@gmail.com

3 Pós-Doutoranda, Programa de Pós-Graduação em Ciências Veterinárias no Semiárido, UNIVASF/CPGCVS, Petrolina, PE, Brasil. E-mail: glayciane gois@yahoo.com.br

4 Pós-Doutorando, Programa de Pós-Graduação em Ciência Animal e Pastagens, Universidade Federal Rural de Pernambuco, UFRPE/UAG, Garanhuns, PE, Brasil. E-mail: flemingcte@yahoo.com.br

Author for correspondence
} 
foi o inteiramente casualizado, em arranjo fatorial $3 \times 7$, (3 tratamentos e 7 dias de aberturas), com três repetições. Os tratamentos constituíram-se de três silagens: silagem de erva sal, silagem de erva sal + raspa de mandioca e silagem de erva sal + sorgo grão moído. O experimento foi conduzido no laboratório de Nutrição Animal da Embrapa Semiárido, localizada no município de Petrolina-PE. Para cada tratamento foram utilizados 21 silos experimentais que foram abertos aos 1, 3, 5, 7, 14, 28 e 56 dias de ensilagem. Foram determinados o pH, nitrogênio amoniacal em relação ao nitrogênio total, matéria seca, proteína bruta, extrato etéreo, matéria mineral, matéria orgânica, fibra em detergente neutro, fibra em detergente ácido, carboidratos totais, carboidrato não fibroso e digestibilidade in vitro da matéria seca. Os aditivos: sorgo grão e raspa de mandioca elevaram o teor de matéria seca e reduziram os valores de $\mathrm{pH}$. Os valores de $\mathrm{N}-\mathrm{NH}_{3} \mathrm{NT}^{-1}$ aumentaram com o decorrer dos processos fermentativos e após 56 dias de fermentação foram próximos a 11\%. No processo fermentativo as silagens foram classificadas como excelentes. A adição da raspa de mandioca e do sorgo grão favorece o processo de ensilagem da erva sal proporcionando melhorias no valor nutritivo da silagem. Durante o período de conservação, a utilização desses aditivos promove redução das perdas totais, inibição da fermentação alcoólica e maior recuperação de carboidratos, resultando em silagem com valor nutritivo semelhante ao de forragem fresca, caracterizando assim como uma fonte alternativa de aditivos.

Palavras-chave: Alimentos. Conservação de forragem. Semiárido. Suplementação.

\section{Introduction}

In the semi-arid regions of northeastern Brazil, the scarcity of food and its low nutritional value, mainly due to rainfall irregularities, are some of the problems that compromise the development of animal production. Small farms in the semiarid region obtain water through cisterns, wells, underground dams or small dams. About 100,000 wells have been drilled to meet the diverse needs of the human and animal populations (MARTINS; NOGUEIRA, 2015).

The use of groundwater is often unfeasible because of a large amount of salts dissolved by the weathering of crystalline rocks, requiring desalination to make the spring viable, providing good quality water. However, this technology generates residues with high salt concentration, because to obtain a certain volume of desalinated water, another volume of saline waste is produced. This residue can be placed in evaporation basins to obtain salt, used in the production of aquatic animals, and for the irrigation of halophytes with forage potential which, besides serving as livestock feed, can help to preserve the regional environmental balance (SANTOS et al., 2010a).

Halophytes are adapted to elevated levels of soil salinity and have the capacity to accumulate high amounts of salts in their tissues through the process of phytoextraction of salts in sodium soils. To do so, the plant must be tolerant to salt excess and high biomass production in this condition. In addition, it must accumulate high salt levels in the aerial part, so that salts can be removed with the plant harvest (PEDROTTI et al., 2015). Because the old man saltbush has high salt content, it can be a reliable source of minerals to meet the demands of ruminants in semi-arid conditions (VALE; AZEVEDO, 2013). The high digestibility coefficient and protein content in its leaves make it a potential resource of nutrient supply, especially during the forage shortage period, and these nutrients can be converted into noble products such as meat, milk, and skin.

The use of preserved forages, especially in the form of silage, is a viable alternative to ensure the provision of high-quality forage during the feed shortage period. The process is based on the fermentation and concomitant production of organic acids responsible for $\mathrm{pH}$ reduction and food preservation (COUTINHO et al., 2015). However, the fermentation process is complex, involving chemical and microbiological variations in the ensiled mass, which can result in good or poorquality silage (MOUSQUER et al., 2013). 
The use of additives can improve the quality of legume silages, providing conditions for good fermentation. Thus, cassava (Manihot esculenta Crantz) is a viable alternative because it is traditionally grown in most of the country. The roots stand out as an energy source, which is the most important component of food rations for different animal species. Sorghum (Sorghum bicolor [L.] Moench) has also been widely used in silage production due to its biomass production potential under water deficit conditions and poor soils, because it is tolerant to diseases and pests, easy to cultivate and preserve, has good nutritional value, is a source of digestible fiber and starch, besides being excellent for animal consumption.

The objective of this study was to evaluate the chemical composition and fermentative characteristics of old man saltbush silage supplemented with energy concentrates.

\section{Material and Methods}

The experiment was carried out at an experimental field in the Caatinga biome located in the Animal Metabolism research center, Brazilian Agricultural Research Corporation (EMBRAPA), in the city of Petrolina (PE), Brazil. The area has an average annual rainfall of $578 \mathrm{~mm}$ and average maximum and minimum temperatures of 33.46 and $20.87^{\circ} \mathrm{C}$, respectively (EMBRAPA, 2011).

The experimental design was completely randomized, in a factorial arrangement $3 \mathrm{x}$ 7, (treatments and opening days), with three replications. The treatments $(\mathrm{T})$ consisted of three silages: T1- old man saltbush silage (SS), T2-SS + cassava scrap ( $10 \%$ of green weight), T3-SS + milled grain sorghum (10\% of green weight). The old man saltbush used for silage production was harvested in the experimental field of EMBRAPA Semiarid, when in full vegetative stage. Forage cutting was done manually, and the material was chopped in a forage machine, obtaining particles of sizes ranging from 2 to 10 centimeters. The chopped material was homogenized and sampled as non-ensiled material (original material), and then ensiled in experimental silos made from "PVC" tubes of $10 \mathrm{~cm}$ in diameter and $50 \mathrm{~cm}$ in length. Table 1 shows the chemical composition of the old man saltbush and additives.

Table 1. Average content of dry matter (DM), organic matter (OM), mineral matter (MM), crude protein (CP), ether extract (EE), neutral detergent fiber (NDF), acid detergent fiber (ADF), total carbohydrates (TC), and non-fibrous carbohydrate (NFC) of the food used to make the silages.

\begin{tabular}{lccc}
\hline \multirow{2}{*}{ Variables } & \multicolumn{3}{c}{ Food } \\
\cline { 2 - 4 } & Old man saltbush & Cassava scrap & Grain sorghum \\
\hline DM & 41.58 & 84.19 & 86.28 \\
OM & 82.82 & 96.49 & 94.07 \\
MM & 17.18 & 3.51 & 5.93 \\
CP & 6.82 & 3.49 & 7.27 \\
EE & 1.09 & 0.74 & 3.21 \\
NDF & 64.37 & 21.28 & 15.41 \\
ADF & 37.00 & 13.20 & 12.00 \\
CHOT & 77.42 & 90.33 & 75.93 \\
NFC & 10.45 & 15.10 & 59.05 \\
IVDMD & 47.59 & 81.23 & 70.34 \\
\hline
\end{tabular}

Sixty-three silos were made in PVC tube to store the chopped forage. The silos were weighed before and after forage deposition to determine the density of the ensiled mass, and silo volume and weight. The 
silos were opened on different days $(1,3,5,7,14$, 28 , and 56 days), and the ensiled material at up to 10 $\mathrm{cm}$ from the edges of the silos was discarded. The remaining material was homogenized and sampled to determine the bromatological composition and fermentation profile, together with the forage sample before being ensiled.

Samples of the in natura material and the silage after silo opening were pre-dried in a forced ventilation oven at $55^{\circ} \mathrm{C}$ for 72 hours and processed in mills with screen sieves of $1 \mathrm{~mm}$ in diameter. The samples were conditioned in polyethylene bottles to determine the contents of dry matter (DM), organic matter $(\mathrm{OM})$, crude protein $(\mathrm{CP})$, neutral detergent fiber (NDF), acid detergent fiber (AFD), and ether extract (EE), according to the recommendations of Silva and Queiroz (2002). In vitro dry matter digestibility (IVDMD) was also determined according to the two-step method of Tilley and Terry (1963), described by Silva and Queiroz (2002). Total carbohydrates (TC) and non-fibrous carbohydrates (NFC) were obtained according to Sniffen et al. (1992), by means of the equations: TC $=100-(\% \mathrm{CP}+\% \mathrm{EE}+\% \mathrm{MM})$, and $\mathrm{NFC}=100-$ $(\% \mathrm{CP}+\% \mathrm{EE}+\% \mathrm{NDF}+\mathrm{MM})$.

An aliquot of $25 \mathrm{~g}$ of wet silage sample was taken and placed in a container with $100 \mathrm{~mL}$ distilled water and then mixed. After one-hour resting, $\mathrm{pH}$ was read using a potentiometer as proposed by Silva and Queiroz (2002). The content of ammoniacal N $\left(\mathrm{N}-\mathrm{NH}_{3}\right)$ was determined as technique proposed by Fenner (1965) and adapted by Vieira (1980). Another aliquot of $25 \mathrm{~g}$ of wet silage was placed in a vessel containing $200 \mathrm{~mL} \mathrm{H}_{2} \mathrm{SO}_{4}(0.2 \mathrm{~N})$, stirred, and allowed to stand for 48 hours under refrigeration. Afterward, the material was filtrated through a fine mesh plastic sieve, lined with gauze. Then, an aliquot of $5 \mathrm{~mL}$ of the filtrate $+10 \mathrm{~mL}$ of potassium hydroxide $(2 \mathrm{~N})$ was filtered and titrated with an $\mathrm{HCl}$ solution, and the readings were noted. The ratio between $\mathrm{N}-\mathrm{NH}_{3}$ and total $\mathrm{N}(\mathrm{TN})$ was calculated using the equation: $\mathrm{N}_{-} \mathrm{NH}_{3}=(\mathrm{N}$ ammoniacal $* 100)$ $\mathrm{NT}^{-1}$. The value of $\mathrm{TN}$ was obtained by dividing the
$\mathrm{CP}$ values by the factor 6.25 (SILVA; QUEIROZ, 2002).

The recommendations of Kung Junior and Ranjit (2001) were adopted for the analysis of organic acids. $1 \mathrm{~mL}$ of metaphosphoric acid $20 \% \mathrm{v} \mathrm{v}-1$ was added to $2 \mathrm{~mL}$ of the filtrate, and the sample was centrifuged. Analyses of organic acids (lactic acid, acetic acid, and butyric acid) were carried out by high-performance liquid chromatography (HPLC) at the Animal Nutrition Laboratory of the Federal University of Minas Gerais (UFMG).

The silages produced had their fermentation processes classified as excellent (90 - 100 points), good (70 - 89 points), regular (50 - 69 points), bad (30 - 49 points), and very bad ( $<30$ points) according to the method proposed by Tomich et al. (2004). This method qualifies silage fermentation process regarding the relationship between $\mathrm{pH}$ and $\mathrm{DM}$ content, the concentration of $\mathrm{N}-\mathrm{NH}_{3} \mathrm{NT}^{-1}$, and butyric and acetic acid contents.

The data were submitted to analysis of variance (ANOVA) and the means were compared by the Tukey test at the $5 \%$ probability level $(\mathrm{P}<0.05)$, using the statistical analysis software SAS (SAS, 2009).

\section{Results and Discussion}

Table 2 shows the mean values for dry matter, mineral matter, organic matter, crude protein, and ether extract of the old man saltbush silages submitted to different treatments and silo-opening times. There was no significant interaction $(\mathrm{P}>0.05)$ for fermentation time and treatment for DM concentrations. DM contents are observed to have been similar at day 56 after ensiling for all silage types evaluated $(\mathrm{P}>0.05)$, with values of $29.66 \%$; $35.76 \% ; 35.94 \%$, for SS, SS+C, SS+S, respectively.

No changes were observed in the DM values of silages in the different opening periods (0 to 56 days), that is, the dry matter remained stable. However, the DM contents of $\mathrm{SS}+\mathrm{C}$ and $\mathrm{SS}+\mathrm{S}$ were similar 
$(\mathrm{P}>0.05)$ and higher than those of SS $(\mathrm{P}<0.05)$. The $\mathrm{DM}$ increase with the addition of cassava scrap and grain sorghum was due to the higher DM content of these additives in relation to old man saltbush.

Table 2. Average contents of dry matter (DM), mineral matter (MM), organic matter (OM), crude protein (CP), and ether extract (EE) of salt grass silages supplemented with energetic concentrates as a function of fermentation days.

\begin{tabular}{|c|c|c|c|c|c|c|c|c|}
\hline \multicolumn{9}{|c|}{ Fermentation Days } \\
\hline Treatments & P0 & $1^{\text {st }}$ & $3^{\text {rd }}$ & $5^{\text {th }}$ & $7^{\text {th }}$ & $14^{\text {th }}$ & $28^{\text {th }}$ & $56^{\text {th }}$ \\
\hline \multicolumn{9}{|c|}{ Dry Matter } \\
\hline SS & $29.44 \mathrm{aB}$ & $28.28 \mathrm{aB}$ & $29.50 \mathrm{aB}$ & $28.32 \mathrm{aB}$ & $31.65 \mathrm{aB}$ & $28.90 \mathrm{aB}$ & $29.76 \mathrm{aB}$ & $29.66 \mathrm{aB}$ \\
\hline $\mathrm{SS}+\mathrm{C}$ & $34.24 \mathrm{aA}$ & $33.34 \mathrm{aA}$ & $36.05 \mathrm{aA}$ & $33.59 \mathrm{aA}$ & $37.44 \mathrm{aA}$ & $34.05 \mathrm{aA}$ & $34.51 \mathrm{aA}$ & $35.76 \mathrm{aA}$ \\
\hline $\mathrm{SS}+\mathrm{S}$ & $35.37 \mathrm{aA}$ & $33.66 \mathrm{aA}$ & $35.45 \mathrm{aA}$ & $33.44 \mathrm{aA}$ & $37.60 \mathrm{aA}$ & $34.91 \mathrm{abA}$ & $33.60 \mathrm{abA}$ & $35.94 \mathrm{aA}$ \\
\hline \multicolumn{9}{|c|}{ Mineral Matter (\% DM ) } \\
\hline SS & $14.91 \mathrm{bA}$ & $13.91 \mathrm{bA}$ & 14.71abA & 16.33abA & 15.50abA & 14.12abA & $16.22 \mathrm{aA}$ & 15.79abA \\
\hline $\mathrm{SS}+\mathrm{C}$ & $13.40 \mathrm{bB}$ & $12.33 \mathrm{bB}$ & $12.77 \mathrm{abB}$ & $13.46 \mathrm{abB}$ & $12.47 \mathrm{abB}$ & $13.11 \mathrm{abB}$ & $13.78 \mathrm{aB}$ & $13.11 \mathrm{abB}$ \\
\hline $\mathrm{SS}+\mathrm{S}$ & $15.27 \mathrm{bA}$ & $13.19 \mathrm{bA}$ & $15.19 \mathrm{abA}$ & $15.01 \mathrm{abA}$ & $14.34 \mathrm{abA}$ & $14.54 \mathrm{abA}$ & $15.44 \mathrm{aA}$ & $13.79 \mathrm{abA}$ \\
\hline \multicolumn{9}{|c|}{ Organic Matter (\% DM ) } \\
\hline SS & $85.09 \mathrm{aB}$ & $86.08 \mathrm{aB}$ & $85.28 \mathrm{abB}$ & $83.66 \mathrm{abB}$ & $84.50 \mathrm{abB}$ & $85.87 \mathrm{abB}$ & $83.77 \mathrm{bB}$ & $84.20 \mathrm{abB}$ \\
\hline $\mathrm{SS}+\mathrm{C}$ & $86.60 \mathrm{aA}$ & $87.66 \mathrm{aA}$ & 87.22abA & 86.53abA & 87.52abA & 86.88abA & $86.21 \mathrm{bA}$ & 86.88abA \\
\hline $\mathrm{SS}+\mathrm{S}$ & $84.75 \mathrm{aB}$ & $86.80 \mathrm{aB}$ & $84.80 \mathrm{abB}$ & 84.99abB & $85.65 \mathrm{abB}$ & $85.45 \mathrm{abB}$ & $84.55 \mathrm{bB}$ & 86.20abB \\
\hline \multicolumn{9}{|c|}{ Crude protein $(\% \mathrm{DM})$} \\
\hline SS & $6.82 \mathrm{aB}$ & $6.85 \mathrm{aB}$ & $7.18 \mathrm{aB}$ & $6.93 \mathrm{aB}$ & $6.73 \mathrm{aB}$ & $7.28 \mathrm{aB}$ & $6.83 \mathrm{aB}$ & $7.36 \mathrm{aB}$ \\
\hline $\mathrm{SS}+\mathrm{C}$ & $6.05 \mathrm{aC}$ & $6.10 \mathrm{aC}$ & $6.07 \mathrm{aC}$ & $6.21 \mathrm{aC}$ & $5.91 \mathrm{aC}$ & $6.17 \mathrm{aC}$ & $6.08 \mathrm{aC}$ & $5.50 \mathrm{aC}$ \\
\hline $\mathrm{SS}+\mathrm{S}$ & $7.27 \mathrm{aA}$ & $7.59 \mathrm{aA}$ & $7.49 \mathrm{aA}$ & $7.56 \mathrm{aA}$ & $7.53 \mathrm{aA}$ & 7.61aA & $7.87 \mathrm{aA}$ & $7.58 \mathrm{aA}$ \\
\hline \multicolumn{9}{|c|}{ Ether extract (\% DM ) } \\
\hline SS & $1.09 \mathrm{bA}$ & $1.98 \mathrm{bA}$ & $2.01 \mathrm{bA}$ & $1.96 \mathrm{bA}$ & $2.13 \mathrm{bA}$ & $2.14 \mathrm{bA}$ & $1.82 \mathrm{bA}$ & $2.28 \mathrm{bA}$ \\
\hline $\mathrm{SS}+\mathrm{C}$ & $1.06 \mathrm{bA}$ & $1.65 \mathrm{bA}$ & $1.20 \mathrm{bA}$ & $1.80 \mathrm{bA}$ & $1.67 \mathrm{bA}$ & $2.04 \mathrm{bA}$ & $1.65 \mathrm{bA}$ & $1.27 \mathrm{bA}$ \\
\hline $\mathrm{SS}+\mathrm{S}$ & $1.95 \mathrm{aA}$ & $2.24 \mathrm{aA}$ & $2.87 \mathrm{aA}$ & $2.92 \mathrm{aA}$ & $2.85 \mathrm{aA}$ & $3.54 \mathrm{aA}$ & $2.92 \mathrm{aA}$ & $3.37 \mathrm{aA}$ \\
\hline
\end{tabular}

$\mathrm{SS}=$ Oldman saltbush Silage; $\mathrm{SS}+\mathrm{C}=$ Old man saltbush Silage + Cassava Scrap; $\mathrm{SS}+\mathrm{S}=$ Old man saltbush Silage + Grain Sorghum; $\mathrm{P} 0=$ Pre-ensiled material; Upper case letters in the same column and lower case in the lines do not differ by Tukey's test ( $\mathrm{P}<0.05)$.

The DM values found in this study for $\mathrm{SS}+\mathrm{C}$ and $\mathrm{SS}+\mathrm{S}$ ranged from 33.34 to $37.44 \%$ and 33.44 to $37.60 \%$, respectively. They are close to the range considered adequate according to McDonald et al. (1991), who state that a dry matter content of $20 \%$ or more associated with an adequate soluble carbohydrate content would be sufficient to produce good quality silage. For the variable MM, no significant interaction $(\mathrm{P}<0.05)$ was observed between the treatments and the different fermentation days. The treatments SS and $\mathrm{SS}+\mathrm{S}$ did not differ from each other $(\mathrm{P}>0.05)$, but were higher $(\mathrm{P}<0.05)$ than $\mathrm{SS}+\mathrm{C}$. This difference can be explained by the fact that old man saltbush and grain sorghum have higher MM contents than cassava scrap. There was no interaction between the different opening times for the OM variable. However, the addition of cassava scrap was observed to promote an increase in $\mathrm{OM}$ contents for the $\mathrm{SS}+\mathrm{C}$ treatment, which was higher than the others were $(\mathrm{P}>0.05)$. This behavior can be explained by the low ash contents in the cassava scrap compared to the old man saltbush, which led to an increase in OM content.

No interaction $(\mathrm{P}<0.05)$ was observed for $\mathrm{CP}$ between treatments as a function of fermentation days. The silage added with grain sorghum was superior to the others $(\mathrm{P}>0.05)$, ranging from 7.27 to $7.87 \%$. The silages were observed to present $\mathrm{CP}$ levels close to the minimum requirements for ruminal functioning, which according to Church 
(1988) are of at least $7 \% \mathrm{CP}$ so that the nitrogen supply is sufficient for effective microbial fermentation in the rumen. However, the old man saltbush silages showed CP values similar to that of silages supplemented with grain sorghum at 30 (7.18\%), 14 (7.28\%), and 56 (7.36\%) days.

According to McDonald et al. (1991), the CP levels remain stable, but their nature changes due to the intense proteolysis. In this study, CP remained stable during silage from the 1 st to the 56th day ( $P>0.05)$, with differences only when comparing $\mathrm{CP}$ contents of the original material $(6.82 \%)$ to the silage on the 56th day $(7.36 \%)(\mathrm{P}<0.05)$. The increase in CP content in the silage supplemented with sorghum reflects the higher percentage of this fraction in the additive compared to the other treatments.

No interaction $(\mathrm{P}>0.05)$ was observed between the treatments for the EE variable and silo opening days. However, significant differences $(\mathrm{P}<0.05)$ were observed between treatments. Silage added with grain sorghum presented higher values than the other treatments $(\mathrm{P}>0.05)$. This behavior was expected because the EE content of this additive is higher than are the others. Oliveira et al. (2012) observed a reduction of 0.02 percentage units for each unit of cassava meal added in elephant grass silage. The author attributes these reductions to the probable low EE levels of the residue used, as well as to the low values of this constituent in elephant grass.

Table 3 shows the levels of total carbohydrate (TC), non-fibrous carbohydrate (NFC), and in vitro dry matter digestibility (IVDMD). No interaction $(\mathrm{P}>0.05)$ was observed between the treatments and the different fermentation days for the variable TC. However, the treatments presented significant differences $(\mathrm{P}<0.05)$. The silage added with cassava scrap showed higher TC contents than the other silages, which did not differ $(\mathrm{P}>0.05)$. This difference can be explained by the higher percentage of this fraction in this additive when compared to old man saltbush, and the cassava scrap stands out, with $90.33 \%$ in its composition. Carbohydrate levels are strongly influenced by $\mathrm{CP}$ and EE values, considering the use of these variables for $\mathrm{TC}$ determination.

An interaction $(\mathrm{P}<0.05)$ was observed between the treatments and fermentation days for NFC values. The highest NFC contents can be observed in the pre-ensiled material and in the first day of silo opening $(\mathrm{P}<0.05)$. The stabilization of the drop in NFC contents occurred from the 14th fermentation day on. The mean values of the other fermentation times presented a similar behavior $(\mathrm{P}>0.05)$. Cassava scrap promoted an increase in NFC contents in the $\mathrm{SS}+\mathrm{C}$ treatment, which was higher than the SS and $\mathrm{SS}+\mathrm{S}$ treatments. These increases in the $\mathrm{FCN}$ fraction may be justified by the fact that cassava meal is very rich in starch. As this fraction consists of soluble sugars and starch, that is, the difference between CHOs and NDF (FERRAZ et al., 2011), probably the residue high starch values increased the fraction contents.

The in vitro digestibility of DM (IVDMD) presented significant interaction $(\mathrm{P}<0.05)$. The oldman saltbush silage and the one supplemented with cassava scrap in the pre-ensiled material did not differ $(\mathrm{P}>0.05)$ in the first opening day, being superior to the silage supplemented with sorghum. As the fermentation days passed, the silages added with cassava scrap were observed to present higher averages than the other treatments $(49.06 \%$, $49.35 \%, 49.99 \%, 49.44 \%, 50.01 \% ; 50.18 \%$, and $48.93 \%$ ). Probably, the increase in IVDMD is due to the high digestibility of the used additive $(81.23 \%)$ when compared to the others.

The NDF contents interacted $(\mathrm{P}<0.05)$ between the treatments as a function of fermentation days. NDF contents are observed to increase up to 50 fermentation days with $64.73 \%$, which is higher than the others are $(\mathrm{P}<0.05)$, and the additive promoted alterations in the cell wall fraction content. However, as fermentation time increases, 
contents decrease. NDF reductions may indicate the action of enzymes on carbohydrates in the cell wall and may increase substrate availability for bacteria. However, Santos et al. (2010b) report that the concentration of cell wall constituents generally increases with the ensiling process due to the loss of soluble nutrients in the gas or effluent form, or according to Van Soest (1994) due to the loss of volatiles during material drying in the greenhouse.

Table 3. Mean values of total carbohydrates (TC) and non-fibrous carbohydrates (NFC), in vitro digestibility of DM (IVDMD), neutral detergent fiber (NDF), and acid detergent fiber (ADF) of herb old man saltbush supplemented with energy concentrates, as a function of fermentation days.

\begin{tabular}{lcccccccc}
\hline \multicolumn{7}{c}{ Fermentation Days } \\
\hline Treatments & P0 & $1^{\text {st }}$ & $3^{\text {rd }}$ & $5^{\text {th }}$ & $7^{\text {th }}$ & $14^{\text {th }}$ & $28^{\text {th }}$ & $56^{\text {th }}$ \\
\hline SS & $77.42 \mathrm{bA}$ & $77.25 \mathrm{bA}$ & $76.08 \mathrm{bA}$ & $74.76 \mathrm{bA}$ & $75.62 \mathrm{bA}$ & $76.44 \mathrm{bA}$ & $76.18 \mathrm{bA}$ & $74.54 \mathrm{bA}$ \\
$\mathrm{SS}+\mathrm{C}$ & $81.81 \mathrm{aA}$ & $79.90 \mathrm{aA}$ & $79.94 \mathrm{aA}$ & $78.51 \mathrm{aA}$ & $79.93 \mathrm{aA}$ & $78.66 \mathrm{aA}$ & $78.46 \mathrm{aA}$ & $80.10 \mathrm{aA}$ \\
$\mathrm{SS}+\mathrm{S}$ & $69.00 \mathrm{bA}$ & $76.96 \mathrm{bA}$ & $74.42 \mathrm{aA}$ & $74.49 \mathrm{bA}$ & $74.49 \mathrm{bA}$ & $75.25 \mathrm{bA}$ & $74.29 \mathrm{aA}$ & $75.34 \mathrm{bA}$ \\
\hline \multicolumn{7}{c}{ Non-fibrous carbohydrates } \\
\hline $\mathrm{SS}$ & $14.42 \mathrm{bA}$ & $14.64 \mathrm{bA}$ & $13.66 \mathrm{bAB}$ & $11.20 \mathrm{bAB}$ & $11.25 \mathrm{bAB}$ & $13.50 \mathrm{bAB}$ & $12.22 \mathrm{bAB}$ & $12.45 \mathrm{bAB}$ \\
$\mathrm{SS}+\mathrm{C}$ & $20.52 \mathrm{aA}$ & $17.72 \mathrm{aA}$ & $15.41 \mathrm{aAB}$ & $13.22 \mathrm{aAB}$ & $13.02 \mathrm{aB}$ & $14.08 \mathrm{aAB}$ & $16.43 \mathrm{aAB}$ & $15.77 \mathrm{bAB}$ \\
$\mathrm{SS}+\mathrm{S}$ & $19.27 \mathrm{bA}$ & $15.72 \mathrm{bA}$ & $12.74 \mathrm{bAB}$ & $12.94 \mathrm{bAB}$ & $14.45 \mathrm{bAB}$ & $12.03 \mathrm{bAB}$ & $12.71 \mathrm{bAB}$ & $14.77 \mathrm{aAB}$ \\
\hline \multicolumn{7}{c}{ In vitro digestibility of DM } \\
\hline SS & $47.59 \mathrm{cA}$ & $48.88 \mathrm{aA}$ & $47.98 \mathrm{abB}$ & $47.34 \mathrm{abB}$ & $48.37 \mathrm{abB}$ & $48.28 \mathrm{abB}$ & $48.72 \mathrm{abB}$ & $47.81 \mathrm{bB}$ \\
$\mathrm{SS}+\mathrm{C}$ & $50.45 \mathrm{bA}$ & $49.06 \mathrm{bA}$ & $49.35 \mathrm{abA}$ & $49.99 \mathrm{abA}$ & $49.44 \mathrm{abA}$ & $50.01 \mathrm{abA}$ & $50.18 \mathrm{aA}$ & $48.93 \mathrm{bA}$ \\
$\mathrm{SS}+\mathrm{S}$ & $48.79 \mathrm{bA}$ & $47.75 \mathrm{bA}$ & $47.78 \mathrm{bB}$ & $48.59 \mathrm{abB}$ & $48.29 \mathrm{abB}$ & $48.68 \mathrm{abB}$ & $48.89 \mathrm{aB}$ & $47.76 \mathrm{bB}$ \\
\hline \multicolumn{7}{c}{ Neutral detergent fiber $(\%$ DM) } \\
\hline SS & $62.32 \mathrm{cC}$ & $61.73 \mathrm{cC}$ & $62.42 \mathrm{cB}$ & $63.56 \mathrm{cA}$ & $62.09 \mathrm{cC}$ & $62.47 \mathrm{cB}$ & $61.69 \mathrm{cC}$ & $61.77 \mathrm{cC}$ \\
$\mathrm{SS}+\mathrm{C}$ & $62.54 \mathrm{bC}$ & $61.94 \mathrm{bC}$ & $63.03 \mathrm{bB}$ & $64.00 \mathrm{bA}$ & $62.25 \mathrm{bC}$ & $63.05 \mathrm{bB}$ & $62.21 \mathrm{bC}$ & $62.42 \mathrm{bC}$ \\
$\mathrm{SS}+\mathrm{S}$ & $63.80 \mathrm{aC}$ & $62.87 \mathrm{aC}$ & $63.82 \mathrm{aB}$ & $64.73 \mathrm{aA}$ & $63.41 \mathrm{aC}$ & $64.16 \mathrm{aB}$ & $63.17 \mathrm{aC}$ & $62.86 \mathrm{aC}$ \\
\hline \multicolumn{7}{c}{ Acid detergent fiber $(\%$ DM) } \\
\hline SS & $37.21 \mathrm{abA}$ & $36.97 \mathrm{abA}$ & $37.05 \mathrm{abA}$ & $37.79 \mathrm{abA}$ & $38.32 \mathrm{abA}$ & $38.48 \mathrm{abA}$ & $38.27 \mathrm{abA}$ & $37.83 \mathrm{abA}$ \\
$\mathrm{SS}+\mathrm{C}$ & $37.92 \mathrm{aA}$ & $38.24 \mathrm{aA}$ & $38.10 \mathrm{aA}$ & $38.27 \mathrm{aA}$ & $38.18 \mathrm{aA}$ & $37.86 \mathrm{aA}$ & $37.78 \mathrm{aA}$ & $37.64 \mathrm{aA}$ \\
$\mathrm{SS}+\mathrm{S}$ & $38.12 \mathrm{aA}$ & $38.09 \mathrm{aA}$ & $37.94 \mathrm{aA}$ & $38.02 \mathrm{aA}$ & $38.16 \mathrm{aA}$ & $37.86 \mathrm{aA}$ & $37.31 \mathrm{aA}$ & $37.27 \mathrm{aA}$ \\
\hline
\end{tabular}

$\mathrm{SS}=$ Old man saltbush Silage; $\mathrm{SS}+\mathrm{C}=$ Old man saltbush Silage + Cassava Scrap; $\mathrm{SS}+\mathrm{S}=$ Old man saltbush Silage + Grain Sorghum; $\mathrm{P} 0=$ Pre-ensiled material; Upper case letters in the same column and lower case in the lines do not differ by Tukey's test $(\mathrm{P}<0.05)$.

Silages added with grain sorghum $(64.73 \%)$ had higher NDF contents, differing significantly $(\mathrm{P}<0.05)$ from the other treatments. In contrast, no interaction $(\mathrm{P}>0.05)$ was observed between the treatments and fermentation days for ADF. The values presented were similar $(\mathrm{P}>0.05)$ in all treatments evaluated, remaining stable throughout the fermentation period. There was an interaction $(\mathrm{P}<0.05)$ between the treatments and the different fermentation days for silage $\mathrm{pH}$ (Table 4). The first fermentation day had $\mathrm{pH}$ of $4.43 ; 4.30 ; 4.40$ for the treatments, which were considered superior to the other treatments in the different fermentation days. Silages did not show any differences for the different fermentation days on days $3,5,7,14,28$, and $56(\mathrm{P}>0.05)$. Their values ranged from 3.56 to 4.10 , and from 3.80 to 4.06 , respectively, which is within the $\mathrm{pH}$ range considered normal (3.6 to 4.2) for silages to be considered of good quality (McDONALD et al., 1991). 
Table 4. Mean $\mathrm{pH}$ and ammoniacal nitrogen content $\left(\mathrm{N}^{-\mathrm{NH}_{3}} \mathrm{NT}^{-1}\right)$, and organic acids concentration of the old man saltbush silages supplemented with energy concentrates, as a function of fermentation days.

\begin{tabular}{lccccccc}
\hline \multicolumn{7}{c}{ Fermentation Days } \\
\hline Treatments & $1^{\text {st }}$ & $3^{\text {rd }}$ & $5^{\text {th }}$ & $7^{\text {th }}$ & $14^{\text {th }}$ & $28^{\text {th }}$ & $56^{\text {th }}$ \\
\hline SS & $4.43 \mathrm{aB}$ & $3.56 \mathrm{aA}$ & $4.10 \mathrm{aA}$ & $3.90 \mathrm{aA}$ & $3.96 \mathrm{aA}$ & $3.93 \mathrm{aA}$ & $3.90 \mathrm{aA}$ \\
$\mathrm{SS}+\mathrm{C}$ & $4.30 \mathrm{aB}$ & $4.00 \mathrm{aA}$ & $4.06 \mathrm{aA}$ & $3.96 \mathrm{aA}$ & $3.80 \mathrm{aA}$ & $4.00 \mathrm{aA}$ & $4.06 \mathrm{aA}$ \\
$\mathrm{SS}+\mathrm{S}$ & $4.40 \mathrm{aB}$ & $4.03 \mathrm{aA}$ & $4.10 \mathrm{aA}$ & $3.90 \mathrm{aA}$ & $3.83 \mathrm{aA}$ & $4.00 \mathrm{aA}$ & $4.00 \mathrm{aA}$ \\
\hline \multicolumn{7}{c}{ Ammoniacal nitrogen $(\%$ of total nitrogen $)$} \\
\hline $\mathrm{SS}$ & $4.64 \mathrm{cB}$ & $7.24 \mathrm{cB}$ & $8.51 \mathrm{cA}$ & $8.75 \mathrm{cA}$ & $9.08 \mathrm{bA}$ & $9.33 \mathrm{bA}$ & $11.53 \mathrm{aA}$ \\
$\mathrm{SS}+\mathrm{C}$ & $4.75 \mathrm{cB}$ & $7.70 \mathrm{cB}$ & $8.86 \mathrm{cA}$ & $8.86 \mathrm{cA}$ & $9.14 \mathrm{bA}$ & $9.29 \mathrm{bA}$ & $11.74 \mathrm{aA}$ \\
$\mathrm{SS}+\mathrm{S}$ & $4.93 \mathrm{cA}$ & $7.98 \mathrm{cA}$ & $8.63 \mathrm{cA}$ & $8.92 \mathrm{cA}$ & $9.10 \mathrm{bA}$ & $9.31 \mathrm{bA}$ & $11.87 \mathrm{aA}$ \\
\hline \multicolumn{7}{c}{ Lactic acid $(\%$ DM) } \\
\hline $\mathrm{SS}$ & $3.90 \mathrm{abcB}$ & $4.71 \mathrm{abcA}$ & $5.29 \mathrm{abcA}$ & $5.86 \mathrm{abA}$ & $6.27 \mathrm{aA}$ & $3.73 \mathrm{abA}$ & $4.53 \mathrm{bcB}$ \\
$\mathrm{SS}+\mathrm{C}$ & $3.46 \mathrm{abA}$ & $4.63 \mathrm{aA}$ & $5.54 \mathrm{aA}$ & $4.76 \mathrm{aA}$ & $5.00 \mathrm{aA}$ & $4.28 \mathrm{aA}$ & $4.55 \mathrm{aA}$ \\
$\mathrm{SS}+\mathrm{S}$ & $3.09 \mathrm{abcB}$ & $4.69 \mathrm{abcA}$ & $5.08 \mathrm{abA}$ & $4.75 \mathrm{abA}$ & $4.40 \mathrm{abA}$ & $4.00 \mathrm{abA}$ & $5.88 \mathrm{aA}$ \\
\hline \multicolumn{7}{c}{ Acetic acid (\% DM) } \\
\hline $\mathrm{SS}$ & $0.78 \mathrm{bcB}$ & $2.30 \mathrm{bcA}$ & $0.94 \mathrm{bcA}$ & $0.86 \mathrm{bA}$ & $2.93 \mathrm{aA}$ & $1.19 \mathrm{aA}$ & $1.99 \mathrm{aA}$ \\
$\mathrm{SS}+\mathrm{C}$ & $2.03 \mathrm{bB}$ & $2.05 \mathrm{bA}$ & $0.76 \mathrm{bA}$ & $0.93 \mathrm{bA}$ & $0.95 \mathrm{bB}$ & $1.23 \mathrm{bA}$ & $2.28 \mathrm{bA}$ \\
$\mathrm{SS}+\mathrm{S}$ & $2.30 \mathrm{bA}$ & $0.69 \mathrm{cB}$ & $0.86 \mathrm{cA}$ & $0.81 \mathrm{aA}$ & $1.07 \mathrm{cB}$ & $1.85 \mathrm{bcA}$ & $2.88 \mathrm{bcA}$ \\
\hline \multicolumn{7}{c}{ Butyric Acid (\% DM) } \\
\hline $\mathrm{SS}$ & $0.02 \mathrm{aA}$ & $0.02 \mathrm{aA}$ & $0.04 \mathrm{aA}$ & $0.02 \mathrm{aA}$ & $0.02 \mathrm{aA}$ & $0.02 \mathrm{aA}$ & $0.03 \mathrm{aA}$ \\
$\mathrm{SS}+\mathrm{C}$ & $0.02 \mathrm{aA}$ & $0.02 \mathrm{aA}$ & $0.03 \mathrm{aA}$ & $0.03 \mathrm{aA}$ & $0.02 \mathrm{aA}$ & $0.02 \mathrm{aA}$ & $0.02 \mathrm{aA}$ \\
$\mathrm{SS}+\mathrm{S}$ & $0.02 \mathrm{aA}$ & $0.02 \mathrm{aA}$ & $0.03 \mathrm{aA}$ & $0.03 \mathrm{aA}$ & $0.02 \mathrm{aA}$ & $0.03 \mathrm{aA}$ & $0.03 \mathrm{aA}$ \\
\hline
\end{tabular}

$\mathrm{SS}=$ Old man saltbush Silage; $\mathrm{SS}+\mathrm{C}=$ Old man saltbush Silage + Cassava Scrap; $\mathrm{SS}+\mathrm{S}=$ Old man saltbush Silage + Grain Sorghum; Upper case letters in the same column and lower case in the lines do not differ by Tukey's test $(\mathrm{P}<0.05)$.

Concerning $\mathrm{N}_{-} \mathrm{NH}_{3} \quad \mathrm{NT}^{-1}$, there was an interaction $(\mathrm{P}<0.05)$ between treatments and the different fermentation days (Table 4). The oldman saltbush silages and silage supplemented with cassava scrap at days 10 and 30 of fermentation were similar $(\mathrm{P}>0.05)$, but different from the silage added with grain sorghum, which was superior $(\mathrm{P}<0.05)$. However, an increase of $\mathrm{N}-\mathrm{NH}_{3} \mathrm{NT}^{-1}$ was observed as early as the third day after ensiling, and it continued to increase until the 56th fermentation day. In addition, no differences were observed among silages from day 5 to 56 of fermentation $(\mathrm{P}>0.05)$, which were superior to those of day 1 to 3.

Thus, the silages that are inserted within the first to the 28th days of fermentation presented ammoniacal nitrogen values below $10 \%$, except on the 56th day. A low $\mathrm{N}^{-\mathrm{NH}_{3}} \mathrm{NT}^{-1}$ content with less than $10 \%$ NT indicates that the storage process did not result in excessive protein breakdown in ammonia. However, a value greater than $15 \%$ means that protein breakage was considerable, silages may be less accepted by animals, and there may be low consumption (FARIA et al., 2007).

The concentration of lactic acid underwent interaction $(\mathrm{P}<0.05)$ between the treatments and the different fermentation days (Table 4). A significant difference $(\mathrm{P}<0.05)$ was observed for the first fermentation day when the cassava scrap promoted an increase in lactic acid concentrations. This difference is also observed on the 56th day when sorghum promotes an increase in lactic acid 
contents when added to the silages. Lactic acid has a higher dissociation constant and is, therefore, the strongest and single most important agent for lowering pH (LEONEL et al., 2009).

Based on the classification criteria used by Breirem and Ulvesli (1960), silages with lactic acid values in the range of 1.5 to $2.5 \%$ are considered of good quality. In this study, the values determined presented a variation of 1.41 to $2.29 \%$ of dry matter, which allows classifying them as "good quality", not only in function of the lactic acid values but also mainly due to the other parameters evaluated, except butyric acid.

There was an interaction $(\mathrm{P}<0.05)$ between treatments and fermentation days (Table 4) for the acetic acid concentration. On the first opening day, the silage supplemented with sorghum appeared better than the other treatments, however on the 3rd day an inversion occurred, and the old man saltbush silages supplemented with cassava scrap had higher results than the silage supplemented with sorghum. The treatments were similar to each other $(\mathrm{P}<0.05)$ for the 5th, 7th, 14th, 28th, and 56th fermentation days.

The presence of moderate concentrations of acetic acid is an important factor in fermentation.
The values found in the experiment ranged from 0.69 to $4.30 \%$, and according to Carvalho et al. (2007), a good preservation of ensiled mass should be found below $0.8 \%$ since, above this level, it is considered critical.

The presence of butyric acid in the ensiled mass is always accompanied by changes in product quality. There was no interaction $(\mathrm{P}>0.05)$ between the treatments and the different fermentation days for the butyric acid variable (Table 4 ). The values found in this study were low, close to zero, indicating a little incidence of the Clostridium bacteria, which are the main producers of butyric acid and have their development stimulated under conditions of high humidity in the silage material, evidencing quality of the silage material.

The density of the ensiled material showed no interaction $(\mathrm{P}>0.05)$ between treatments and fermentation the days (Table 5). Higher density $(\mathrm{P}<0.05)$ was observed for the 56th fermentation day, followed by the 1st, 3rd, and 28th. They were not different from each other $(\mathrm{P}>0.05)$. These results can be explained by the better fermentation at higher densities due to the absence of air, and the lower loss of effluent in the silages. Lower values were observed for the 5th; 7th; and 14th opening days.

Table 5. Average contents (\%) of dry matter loss and density for old man saltbush silages supplemented with energy concentrates, as a function of fermentation days.

\begin{tabular}{|c|c|c|c|c|c|c|c|}
\hline & \multicolumn{7}{|c|}{ Fermentation Days } \\
\hline Treatments & $1^{\text {st }}$ & $3^{\text {rd }}$ & $5^{\text {th }}$ & $7^{\text {th }}$ & $14^{\text {th }}$ & $28^{\text {th }}$ & $56^{\text {th }}$ \\
\hline \multicolumn{8}{|c|}{ Density $\left(\mathrm{kg} / \mathrm{m}_{3}\right)$} \\
\hline SS & $943 \mathrm{aA}$ & $891 \mathrm{aA}$ & $804 \mathrm{aA}$ & $870 \mathrm{aA}$ & $850 \mathrm{aA}$ & $831 \mathrm{aA}$ & $910 \mathrm{aA}$ \\
\hline $\mathrm{SS}+\mathrm{C}$ & $910 \mathrm{aA}$ & $900 \mathrm{aA}$ & $911 \mathrm{aA}$ & $882 \mathrm{aA}$ & $840 \mathrm{aA}$ & $841 \mathrm{aA}$ & $930 \mathrm{aA}$ \\
\hline $\mathrm{SS}+\mathrm{S}$ & $979 \mathrm{aA}$ & $961 \mathrm{aA}$ & $971 \mathrm{aA}$ & $918 \mathrm{aA}$ & $918 \mathrm{aA}$ & $841 \mathrm{aA}$ & $911 \mathrm{aA}$ \\
\hline \multicolumn{8}{|c|}{ DM losses $(\%)$} \\
\hline SS & $0.01 \mathrm{bA}$ & $0.01 \mathrm{bA}$ & $0.01 \mathrm{bA}$ & $0.01 \mathrm{bA}$ & $0.08 \mathrm{aA}$ & $0.05 \mathrm{abB}$ & $0.03 \mathrm{aA}$ \\
\hline $\mathrm{SS}+\mathrm{C}$ & $0.02 \mathrm{aA}$ & $0.01 \mathrm{aA}$ & $0.01 \mathrm{bA}$ & $0.01 \mathrm{bA}$ & $0.03 \mathrm{bB}$ & $0.03 \mathrm{aA}$ & $0.03 \mathrm{aA}$ \\
\hline $\mathrm{SS}+\mathrm{S}$ & $0.01 \mathrm{aA}$ & $0.01 \mathrm{aA}$ & $0.02 \mathrm{aA}$ & $0.01 \mathrm{aA}$ & $0.05 \mathrm{aB}$ & $0.03 \mathrm{aB}$ & $0.02 \mathrm{aA}$ \\
\hline
\end{tabular}

$\mathrm{SS}=$ Old man saltbush Silage; $\mathrm{SS}+\mathrm{C}=$ Old man saltbush Silage + Cassava Scrap; $\mathrm{SS}+\mathrm{S}=$ Old man saltbush Silage + Grain Sorghum; Upper case letters in the same column and lower case in the lines do not differ by Tukey's test $(\mathrm{P}<0.05)$. 
All the silages were well compacted, presenting a desirable density, as recommended by Nussio (1997), who states that silage density in the range between 600 and $900 \mathrm{~kg} / \mathrm{m} 3$ is adequate compaction for the ensiling process. Although high values were obtained for the ensiled material density, this fact did not guarantee a better fermentation process or lower DM losses. In other words, the density of the silage material cannot be considered as a determinant of silage quality, and all the forage bromatological and fermentative characteristics must be analyzed.

As for dry matter losses, there was an interaction $(\mathrm{P}>0.05)$ between the treatments and fermentation days. Days 1st; 3rd; 5th; 7th, and 56th were observed to present similar averages $(\mathrm{P}>0.05)$ and were different from the other periods $(\mathrm{P}<0.05)$. Low values were observed for dry matter losses, with averages varying from 0.01 to $0.32 \%$. Possibly, dry matter losses in low percentages are related to the low proteolysis of the ensiled material during fermentation.

According to Edvan et al. (2013), pH values between 3.8 and 4.2 are desirable for silage considered to be well conserved. However, $\mathrm{pH}$ alone cannot be considered as a safe criterion for the evaluation of silages, because its inhibitory effect on plant bacteria and enzymes depends on the decline rate of the ionic concentration and the humidity level of the medium.

When the fermentation process of the silages was analyzed through the model proposed by Tomich et al. (2004) for $\mathrm{pH}$ and ammoniacal nitrogen, silages of all treatments ( $\mathrm{SS}, \mathrm{SS}+\mathrm{C}, \mathrm{SS}+\mathrm{S}$ ), were observed to present scores (100 points) to be classified as excellent, as seen in Table 6. This classification reveals that old man saltbush can be conserved in the form of silage and is equivalent to or even superior to the silages of other tropical forages already used in the feeding of ruminants in other Brazilian regions.

Table 6. Qualification of silage fermentation as a function of dry matter content, $\mathrm{pH}$, and ammoniacal nitrogen as a proportion of the total nitrogen $\left(\mathrm{N}-\mathrm{NH}_{3} \mathrm{NT}^{-1}\right)$ of old man saltbush silages supplemented with energy concentrates.

\begin{tabular}{ccccc}
\hline Treatments & Average DM & Average $\mathrm{pH}$ & Average $\mathrm{NH}_{3} \mathrm{NT}^{-1}(\%)$ & Score \\
\hline $\mathrm{SS}$ & $29.44 \mathrm{~B}$ & $3.96 \mathrm{~A}$ & $8.44 \mathrm{~A}$ & $100 /$ Excellent \\
$\mathrm{SS}+\mathrm{C}$ & $34.87 \mathrm{~A}$ & $4.02 \mathrm{~A}$ & $8.62 \mathrm{~A}$ & $100 /$ Excellent \\
$\mathrm{SS}+\mathrm{S}$ & $34.99 \mathrm{~A}$ & $4.03 \mathrm{~A}$ & $8.67 \mathrm{~A}$ & $100 /$ Excellent \\
\hline
\end{tabular}

$\mathrm{SS}=$ Old man saltbush Silage; $\mathrm{SS}+\mathrm{C}=$ Old man saltbush Silage + Cassava Scrap; $\mathrm{SS}+\mathrm{S}=$ Old man saltbush Silage + Grain Sorghum; Upper case letters in the same column and lower case in the lines do not differ by Tukey's test $(\mathrm{P}<0.05)$.

\section{Conclusion}

The addition of cassava scrap and grain sorghum favors the old man saltbush ensiling process, providing improvements in the silage nutritional value.

Using these supplements during the storage period promotes a reduction of total losses, inhibition of alcoholic fermentation, and recovery of carbohydrates, resulting in silage with a nutritional value similar to that of fresh forage, characterizing it as an alternative supplement source.

\section{References}

BREIREM, K.; ULVESLI, O. Ensiling methods. Herbage. Abstracts, Fort Collins, v. 30, n. 1, p. 1-8, 1960.

CARVALHO, G. G. P.; GARCIA, R.; PIRES, A. J. V.; AZEVÊDO, J. A. G.; FERNANDES, F. É. P.; PEREIRA, O. G. Valor nutritivo e características fermentativas de silagens de capim-elefante com adição de casca de café. Revista Brasileira de Zootecnia, Viçosa, MG, v. 36, n. 6, p. 1875-1881, 2007.

$\mathrm{CHURCH}, \mathrm{D}$. C. The ruminant animal digestive physiology and nutrition. Prentice Hall: New Jersey, 1988. $564 \mathrm{p}$. 
COUTINHO, J. J. O.; COURA, R. A. N.; RODRIGUES, L. M.; ATHAYDE, A. A. R. Efeito de aditivo em silagens de leguminosas forrageiras. Ciência et Praxis, Belo Horizonte, v. 8, n. 15, p. 53-57, 2015.

EDVAN, R. L.; CARNEIRO, M. S. S.; COUTINHO, M. J. F.; SILVA, E. B.; OLIVEIRA, G. S.; SILVA, M. S. M.; ALBUQUERQUE, D. R. Perdas e composição bromatológica de silagem de gliricídia contendo diferentes níveis de vagem de algaroba. Tecnologia \& Ciência Agropecuária, João Pessoa, v. 7, n. 2, p. 63-68, 2013.

EMPRESA BRASILEIRA DE PESQUISA AGROPECUÁRIA-EMBRAPA. Dados meteorológicos. Petrolina, EMBRAPA Semiárido, 2011. Disponível em: $\quad<$ http://www.cpatsa.embrapa.br:8080/index. php?op=dadosmet\&mn=3>. Acesso em: 4 mar. 2016.

FARIA, D. J. G.; GARCIA, R.; PEREIRA, O. G.; FONSECA, D. M.; MELLO, R.; RIGUEIRA, J. P. S. Composição químico-bromatológica da silagem de capim-elefante com níveis de casca de café. Revista Brasileira de Zootecnia, Viçosa, MG, v. 36, n. 2, p. 301308, 2007.

FENNER, H. Methods for determining total volatile bases in rumen fluid by steam distillation. Journal of Dairy Science, United States, v. 48, n. 3, p. 249-251, 1965.

FERRAZ, D. A.; OLIVEIRA, H. C.; GARCIA, R.; PIRES, A. J. V.; OLIVEIRA, A. C.; ALMEIDA, V. V. S. Fracionamento de carboidratos das silagens de cana-deaçúcar com ureia e farelo de mandioca. Revista Científica Produção Animal, Piauí, v. 13, n. 1, p. 33-37, 2011.

KUNG JUNIOR, L.; RANJIT, N. K. The effect of Lactobacillus buchneri and other additives on the fermentation and aerobic stability of barley silage. Journal of Dairy Science, v. 84, n. 5, p. 1149-1155, 2001.

LEONEL, F. P.; PEREIRA, J. C.; COSTA, M. G.; MARCO JÚNIOR, P.; SILVA, C. J.; LARA, L. A. Consórcio capim-braquiária e milho: comportamento produtivo das culturas e características nutricionais e qualitativas das silagens. Revista Brasileira de Zootecnia, Viçosa, MG, v. 38, n. 1, p. 166-176, 2009.

MARTINS, C. A. S.; NOGUEIRA, N. O. Captação de água da chuva em propriedades rurais. Nucleus, Ituverava, v. 12, n. 1, p. 87-106, 2015.

McDONALD, P.; HENDERSON, A. R.; HERON, S. J. E. The biochemistry of silage. New York: Chalcombe Publications, 1991. $339 \mathrm{p}$.

MOUSQUER, C. J.; SILVA, M. R.; CASTRO, W. J. R.; FERNANDES, G. A.; FERNANDES, F. F. D.; SILVA
FILHO, A. S.; FEIJÓ, L. C.; FERREIRA, V. B. Potencial de utilização de silagem de gramíneas tropicais não convencionais e cana-de-açúcar. PUBVET, Maringá, v. 7, n. 22, p. 1-36, 2013.

NUSSIO, L. G. Produção de silagem de sorgo. In: LOPES, M. A.; DURÃES, F. O. M.; OLIVEIRA, A. C.; SILVA, A. F.; PAIVA, E.; MAGALHÃES, P. C.; SANTOS, J. P. Manejo cultural de sorgo para forragem. Sete Lagoas: EMBRAPA - CNPMS, 1997. p. 53-55.

OLIVEIRA, A. C.; GARCIA, R.; PIRES, A. J. V.; OLIVEIRA, H. C.; ALMEIDA, V. V. S.; VELOSO, C. M.; ROCHA NETO, A. L.; OLIVEIRA, U. L. C. Farelo de mandioca na ensilagem de capim-elefante: fracionamento de carboidratos e proteínas e características fermentativas. Revista Brasileira de Saúde e Produção Animal, Salvador, v. 13, n. 4, p. 1020-1031, 2012.

PEDROTTI, A.; CHAGAS, R. M.; RAMOS, V. C.; PRATA, A. P. N.; LUCAS, A. A. T.; SANTOS, P. B. Causas e consequências do processo de salinização dos solos. Revista Eletrônica em Gestão, Educação e Tecnologia Ambiental, Santa Maria, v. 19, n. 2, p. 13081324, 2015.

SANTOS, M. V. F.; GÓMEZ CASTRO, A. G.; PEREA, J. M.; GARCÍA, A.; GUIM, A.; PÉREZ HERNÁNDEZ, M. Fatores que afetam o valor nutritivo das silagens de forrageiras tropicais. Archivos de Zootecnia, Córdoba, v. 59, n. 1, p. 25-43, 2010a.

SANTOS, R. S. S.; DIAS, N. S.; SOUSA NETO, O. N.; GURGEL, M. T. Uso do rejeito da dessalinização de água salobra no cultivo da alface (Lactuca sativa L.) em sistema hidropônico NTF. Ciência e Agrotecnologia, Lavras, v. 34, n. 4, p. 983-989, 2010 b.

SILVA, D. J.; QUEIROZ, A. C. Análise de alimentos: métodos químicos e biológicos. Viçosa, MG: Editora UFV, 2002. 235 p.

SNIFFEN, C. J.; O'CONNOR, D. J.; Van SOEST, P. J.; FOX, D. G.; RUSSELL, J. B. A net carbohydrate and protein system for evaluating cattle diets: carbohydrate and protein availability. Journal of Animal Science, Champaign, v. 70, n. 11, p. 3562-3577, 1992.

STATISTICAL ANALYSIS SYSTEM - SAS. SAS system: SAS/STAT. Version 9.2 (software). Cary: SAS Institute, 2009.

TILLEY, J. M. A.; TERRY, R. A. A two stage technique for the in vitro digestion of forage crops. Journal of the British Grassland Society, Oxford, v. 18, n. 2, p. 104-111, 1963.

TOMICH, T. R.; GONÇALVES, L. C.; TOMICH, R. G. P.; RODRIGUES, J. A. S.; BORGES, I. Características 
químicas e digestibilidade in vitro de silagens de girassol. Revista Brasileira de Zootecnia, Viçosa, MG, v. 33, n. 6, p. 1672-1682, 2004.

VALE, M. B.; AZEVEDO, P. V. Avaliação da produtividade e qualidade do capim elefante e do sorgo irrigados com água do lençol freático e do rejeito do dessalinizador. Revista HOLOS, Natal, v. 3, n. 1, p. 185$195,2013$.
VAN SOEST, P. J. Nutritional ecology of the ruminant. $2^{\text {th }}$ ed. Ithaca: Cornell University Press, 1994. 476 p.

VIEIRA, P. F. Efeito do formaldeido na proteção de proteínas e lipídeos em rações para ruminantes. 1980. Tese (Doutorado em Zootecnia) - Universidade Federal de Viçosa, Viçosa, MG. 